\title{
Integrating spirituality and rationality the long and arduous journey of the historical development of theological training in the Apostolic Faith Mission of South Africa
}

\begin{tabular}{|c|c|}
\hline \multicolumn{2}{|c|}{$\begin{array}{l}\text { Authors: } \\
\text { Marius } \mathrm{Nel}^{1} \\
\text { Fika Janse van Rensburg }\end{array}$} \\
\hline \multicolumn{2}{|c|}{$\begin{array}{l}\text { Affiliations: } \\
{ }^{1} \text { Faculty of Theology, } \\
\text { North-West University, } \\
\text { Potchefstroom Campus, } \\
\text { South Africa }\end{array}$} \\
\hline \multicolumn{2}{|c|}{$\begin{array}{l}\text { Corresponding author: } \\
\text { Marius Nel, } \\
\text { nel.marius1@gmail.com }\end{array}$} \\
\hline \multicolumn{2}{|c|}{$\begin{array}{l}\text { Dates: } \\
\text { Received: } 23 \text { Feb. } 2015 \\
\text { Accepted: } 09 \text { June } 2015 \\
\text { Published: } 04 \text { May } 2016\end{array}$} \\
\hline \multicolumn{2}{|c|}{$\begin{array}{l}\text { How to cite this article: } \\
\text { Nel, M. \& Janse van } \\
\text { Rensburg, F., 2016, } \\
\text { 'Integrating spirituality and } \\
\text { rationality the long and } \\
\text { arduous journey of the } \\
\text { historical development of } \\
\text { theological training in the } \\
\text { Apostolic Faith Mission of } \\
\text { South Africa', In die Skriflig } \\
\text { 50(2), a1943. http://dx.doi. } \\
\text { org/10.4102/ids.v50i2.1943 }\end{array}$} \\
\hline \multicolumn{2}{|c|}{$\begin{array}{l}\text { Copyright: } \\
\text { (c) 2016. The Authors. } \\
\text { Licensee: AOSIS. This wo } \\
\text { is licensed under the } \\
\text { Creative Commons } \\
\text { Attribution License. }\end{array}$} \\
\hline \multicolumn{2}{|l|}{ Read online: } \\
\hline 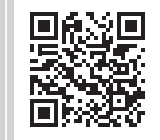 & $\begin{array}{l}\text { Scan this QR } \\
\text { code with your } \\
\text { smart phone or } \\
\text { mobile device } \\
\text { to read online. }\end{array}$ \\
\hline
\end{tabular}

The chequered path of the development of theological training in the Apostolic Faith Mission of South Africa (AFM of SA) started with animosity towards any form of training in favour of the presumed equipment provided by the anointment with the Spirit. Later it led to recognition of the need for better training in the form of Bible school equipment for ministering in assemblies. Finally, the need for proper theological training was acknowledged. The composition of the church's membership and the way it was treated by other denominations influenced the way the Pentecostal Movement defined its stance towards theological training. In this article the AFM of SA's journey and development of its viewpoint towards theological training will be discussed.

\section{Introduction}

On the matter of training, Warrington (2003:30) asks a question that is relevant from a Pentecostal perspective: 'Would Jesus have sent his disciples to Bible school?'1 ${ }^{1}$ The question might seem nonsensical to reformed readers, but it is relevant in the Pentecostal Movement where theological training was initially seen as an obstacle to effective ministry. Eventually it allowed for Bible school training with its emphasis on the exclusive study of only the Bible.

The Pentecostal Movement originated at the beginning of the 20th century with believers receiving what they perceived to be the baptism in the Spirit, with the accompanying speaking in tongues (Friesen 2009:43). In most instances, these believers were either illiterate or theologically illiterate although they immediately started witnessing about the Pentecostal blessing they had received (Anderson 1979:77). Some of them became leaders in assemblies that grew from their witnessing. It is important to note that the early membership of Pentecostal assemblies did not consist of professional, academically trained people, but of peasants, artisans and labourers, along with other less fortunate people.

In those first 30 to 40 years, Pentecostals frowned upon any kind of theological training, because they argued that believers only needed the Spirit's guidance (Letson 2007:115). In most instances members were not academically or theologically educated and did not value further education in this regard. They argued that Jesus promised that the Spirit would give believers the words they need when they bear witness of their faith or defended their convictions. ${ }^{2}$ Early Pentecostals believed that they need no other equipment. They placed emphasis on Bible knowledge, which they understood in a simplistic and fundamentalist way. They deemed theological knowledge unnecessary (Erasmus 1996:13) and dangerous to a Spirit-filled Christian in the sense that

\begin{abstract}
1.Jesus' answer would have been negative. He lived in a world where only education principles that valued Jewish models of education, which was elitist and male-centred, were viewed as valid. However, Jesus did not teach according to Greek, Roman or Jewish education models. We do not know that Jesus was ordained as a rabbi during an official ordainment by three men with the laying on of hands, nor did he operate like other rabbis. He did not follow the learning of others. He did not base himself in one location, preferring to itinerate. He was an inspired mediator of new revelations (Warrington 2003:35). Warrington (2003:44) concludes that Jesus would not have sent his disciples for discipleship training; He trained them on-site by means of his exemplary way of living and by personally teaching them. He probably might have utilised a Bible school for theological education to equip his disciples in a secular world.

2. 'When they deliver you over, do not be anxious how you are to speak or what you are to say, for what you are to say will be given to you in that hour' (Mt 10:19, ESV). 'The baptism of the Holy Spirit is power and understanding of the Word and the glory of God upon your life ... The man that hears you speak a message right from the throne falls down and seeks God and gets up to report that God is in you of truth' (Anon. 1908:2). Charles Parham emphasised the benefits of the Spirit's work as teacher and guide in personal Bible study and in witnessing. No one can interpret the Scriptures correctly without the Spirit's wisdom (Friesen 2009:52).
\end{abstract}

Note: Fika van Rensburg was coopted to participate in the article because of his direct involvement as Dean of the Faculty of Theology (Potchefstroom Campus) in concluding agreements between Pentecostal partners and the North-West University for providing theological training. 
theology will undermine belief (Van der Spuy 1985:107). ${ }^{3}$ They understood speaking in tongues to be the only necessary equipment to evangelise people from different tongues. Some of the early Pentecostals even went on missionary tours to the areas where they believed they had been called and equipped to preach, only to find that their new tongues showed no affinity with existing languages (Robeck 2006:21).

\section{Theological training in the Pentecostal Movement and the Apostolic Faith Mission of South Africa}

In this article the historical development of theological training within the AFM of SA is addressed by means of an inductive manner by the review of available resources. In the early Pentecostal Movement as well as in the Apostolic Faith Mission of South Africa (AFM of SA), leadership developed through the local church, which they viewed as the body of Christ, the place where he is and the instrument through which he lives and works (Langerman 1983:124). They expressed the priesthood of all believers in their emphasis on the participation of all believers in the worship service (Garrard 2009:92). Men and women, young and old were involved in witnessing, preaching, singing and worshiping, and praying for the needy and sick. Anyone who felt the anointing of the Spirit could preach and all who were born again were expected to witness (Burger 1987:181). Members who served as elders, deacons or missionaries with distinction were awarded with certificates that acknowledged their gifting (AFM of SA 1961:284-292; Langerman 1983:125). ${ }^{4}$ Only the bigger assemblies employed full-time leaders and only at a later stage. They did not use any titles, except that all members called each other 'brother' and 'sister' ${ }^{5}$ They confessed that any member could be called by God and anointed by his Spirit. His or her ministry was only confirmed by the certificate issued by the Executive Council (Van der Spuy 1985:105-106). The church did not require any theological training for any of the levels of ministry. This was also the case in the Pentecostal Movement at large. ${ }^{6}$ Not many showed interest in formal academic theological reflection (Eybers, König \& Stoop 1978:174).

The AFM of SA started as a unified church with members of all races attending its worship services. It conducted its services in English with an interpreter for black attendees

3. There are contemporary Pentecostal theological students who witness to the fact that their exposure to theological studies led to the abandonment of their naive faith due to its emphasis on critical and sceptical thinking (Ma 2005:8-9; Mare 2005:433).

4.Langerman (1983) revitalises these concepts as a model for church renewal within the AFM of SA where the professionalisation of the ministry replaced the priesthood of all believers.

5. Some exceptions existed: John G. Lake was called 'brother', but advertised as 'doctor' because of his presumed success in ministering divine healing. Pieter L. le Roux was often referred to as 'pastor' due to his initial involvement in the ministry of the Dutch Reformed Church. 6. George Fox (1624-1691), an English Dissenter and founder of the Religious Society
of Friends, commonly known as the Quakers or Friends, already emphasised that of Friends, commonly known as the Quakers or Friends, already emphasised that
the preacher does not need formal theological training, but rather the guidance of the Spirit in interpreting and proclaiming the gospel (Craven 2009:69).
(Chandomba 2007:20; Reidt 1989:40). ${ }^{7}$ Already within the first 5 years of its existence, the AFM of SA started to follow a policy of segregation, which was not at that stage politically defined and instituted, but was determined by the South African racial reality (AFM of SA 1917:36, Minutes of the Black Executive Council; Pillay 1994:190). Assemblies developed separately in geographical areas, which were racially determined. Theological training would eventually also be determined by two different bodies: the Workers' Council of the white AFM of SA assemblies for white members, and the Missionary Council of the black, Indian and so-called mixed race AFM of SA churches under control of white missionaries (AFM of SA 1909:37, Minutes of the White Executive Council).

The church did not offer any formal theological training and the AFM of SA did not consider it necessary for a church worker to have a sound theological basis. The supposition was that the believer's study of the Bible and equipment with the gifts of the Spirit, including prophecy, words of wisdom and knowledge as well as interpretation of tongues would be adequate for the ministry (Nel 1993:12). ${ }^{8}$ The minutes of the White Workers' Council of 1936 explains that the Holy Spirit should lead people who minister in the AFM of SA, rather than being people guided by an acquired or conditioned ministry that was perceived as characteristic of the ministry in the traditional Afrikaans churches (AFM of SA 1936:1726, Minutes of the White Workers' Council).

Du Plessis (1984) explains the strong view against any formal academic training in terms of a reaction against:

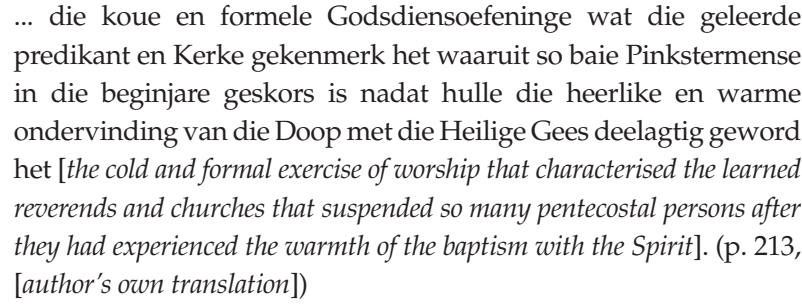

Hayford (2006:16) also refers to the Pentecostal church's experience of marginalisation and dismissal by the larger

7. When a black man, Elias Letwaba, attended a meeting of Lake's assembly in the Central Tabernacle in Bree Street, Johannesburg, Lake put his arm around him, addressing him as 'my brother'. Some whites in the audience were infuriated. Lake retorted, 'My friends, God has made of one blood all nations of the world. If you do not want to acknowledge them as your brothers, then you'll have the mortification of going away into eternal woe, while you see many of these black folk going to eternal bliss. Whosoever hateth his brother is a murderer; and ye know that no murderer hath eternal life abiding in him' (Reidt 1989:43). When some white wanted to kick the 'black devils' out, Lake said calmly, 'If you turn out these men, then you must turn me out too, for I will stand by my black brethren.' Letwaba played a leading role in establishing a black Bible school, although Reidt (1989:43) is not correct in stating that Letwaba was later the one to take over from Lake when he returned to America. Pieter Louis le Roux, a white missionary, was appointed as president of the AFM of SA (Burger 1987:226; Wessels 2009:373).

8. Möller (1975:272) remarks that in the beginning Pentecostals, as a rule, did not attach much value to literacy and higher education. Many came from the working class and argued: 'Why should our children be something else than what we are?' Furthermore, a strong expectation of the second coming of Christ determined their way of thinking. Pentecostals who wanted to study, was told by their parents that it is not worth wasting their time at university when the coming of the Lord is imminent ... more than any movement before, Pentecostals believed thei movement was the "latter rain", a final restoration of the church just before the end For most Pentecostals this made the rest of church history irrelevant. With Christ's second coming so close at hand, why look back? There was too much work to do reaching a lost world' (Hayford 2006:28). Why waste time studying theology when people in the meantime are dying in their sins? 
churches and the secular media for much of the 20th century and how the movement reacted by vying for acceptance. The Pentecostal Movement associated theological endeavours with the existing mainstream denominations, and Pentecostals associated theology with the formalism that it perceived in these churches (Rance 2008:14). ${ }^{9}$

The AFM of SA viewed itself as a missionary movement of the Spirit, a restoration of the ministry of the Spirit that presumably determined the Early Church. It did not want to become a church, but wanted to remain a revival movement conquering new missionary fields. ${ }^{10}$ For this reason it held its worship services in halls instead of devoted church buildings, even when the assembly had acquired property. The arrangement in the hall purposefully avoided any association with the churches of the mainstream denominations who were deemed as formalistic. This included the avoidance of pulpits, pipe organs, a set liturgy and a formal sermon by an ordained priest or reverend (Burger 1987:181-183; Wessels 2009:379).

Because of the anti-institutional church sentiment, the AFM of SA initially rejected any allusion to theological training, because it sounded too much like the practice of the established churches (Burger \& Nel 2008:141). Pentecostal leaders in time found that their lack of theological training caused the community to be prejudiced, closing doors for them to serve on school boards, being appointed as marriage officials and taking part in the SABC's religious broadcasts (Putter 2010b:1). After World War 2 the AFM of SA joined the Pentecostal drive for acceptance and respectability when more members came from the middle class (Anderson 1979:xi). This eventually motivated the church to discuss the need for equipping evangelists and preachers for local ('non-white') $)^{11}$ assemblies as well as white missionaries (AFM of SA 1939:2104, Minutes of the White Workers) by creating 'Bible school training'. ${ }^{12}$ Theoretical training was scheduled for one year and it was combined with two years of practical training (AFM of SA 1944:2623, Minutes of the White Executive Council).

\section{Era of Bible schools}

'Bible school training' consisted of training to acquire a basic knowledge of biblical data and the application of the Bible's content in daily ministry. In the beginning, Pentecostals used

9.Pentecostals shared the perception that learned reverends from traditional denominations did not succeed in mediating an encounter with God, while illiterate laity within the AFM of SA preached the gospel powerfully, leading to conversion attested by signs and wonders. They referred to 1 Corinthians 2:1-6 and 2 Corinthians 3:6 to justify their way of reasoning (Van der Spuy 1985:106). Putte (2009:194) shows that they did not understand that the signs and wonders were in

10.Van Staden (1980:167) relates that Justus du Plessis, General Secretary of the AFM of SA (01 April 1970-30 April 1982), spoke about the fact that the AFM of SA received a property in 1908 as a gift to build a church, but experienced difficulties in the registration of the property, because it was not a legal persona. The AFM of SA did not want to become an established church, but wished to retain the revival spirit of the movement. Only in 1961 did it become a church through a Private Law of Parliament (Apostolic Faith Mission of South Africa 1964b:9).

11.The Apartheid jargon from the sources is retained without the authors of this article sharing the sentiment.

12.Carlisle's opinion (1932:21) illustrates the developing sentiments: 'In the early days of the Latter Rain world-wide outpouring of the Holy Ghost, Bible Schools were condemned and certainly not appreciated by many leaders in this work, but it is quite true to state that today, leaders whose opinions are valued are practically quite true to state that today, leaders whose opinions are valued are practically
unanimous in proclaiming the need of a Bible training, that the man of God may be perfect, thoroughly furnished unto all good works.' the Bible rather superficially and interpreted it literally before it was pragmatically applied (Barr 1983:27). They avoided critical or systematic thinking that could be associated with theological or academic expertise, because Pentecostals regarded such knowledge as endangering the individual's faith and corrupting the church (Chan 2000:45). Pentecostals might possibly have concealed their feelings of inferiority behind the self-assessment of the superiority of their spiritual qualities based on their strong faith in the Word of God - making the necessity for theological reflection seem superfluous. $^{13}$

At the Workers' Council of 1920 it was decided that the church should establish a Bible school in Cape Town to prepare missionaries. It should not be a theological institution as in the case of the other churches, but its training should be concerned with understanding the Bible correctly (AFM of SA 1920b, Minutes of the Workers' Council). S. Moffat, a 'Wesleyan Methodist Local Preacher' according to Lake, was the principal (Burger 1987:234; Wessels 2009:376).

Elias Letwaba (1870-1959) was the pioneer in the AFM of SA to train black pastors in Potgietersrus (Mokopane). The Executive Council of the AFM of SA approved his application to establish a 'black' Bible school on 3 February 1922 (Erasmus 1996:25-42; Pillay 1994:191). ${ }^{14}$ Letwaba also established a primary school for 150 pupils adjunct to his Patmos Bible School (Chandomba 2007:21).

Since 1920 the AFM of SA put the subject of Bible school training for white assembly leaders on the agenda and discussed it at several Workers' Council meetings (AFM of SA 1920a:410; 1921:471; 1923:654; 1926:945; 1949; 1950a; 1958; $1964 ; 1969 ; 1973 b ; 1976 ; 1987$, Minutes of the White Executive Council), leading to vigorous differences of opinion. Many participants in the debate regularly emphasised that Bible school training should not be compulsory for anyone. When a person shows proof of God's calling in his or her life the AFM of SA was prepared to let them enter the ministry without any formal training. The view was that a believer only needs the equipment provided by the Spirit to be a minister of the Word (De Beer 2013:342-343). The AFM of SA established a white Bible school only in 1929 with a female American missionary, Henrietta Fruen, as the principal. The first six full-time students started attending this school in February 1931. Before the end of the year she resigned from her position as principal and in 1932 also as a member of the AFM of SA. She stated as reason for her resignation that the leaders of the church did

13.Cf. Armstrong's discussion (2014:276) of a group's response to suppression, or even the fear of annihilation. She indicates how their horizons tend to shrink and that they may lash out violently, though normally they confine their antagonism to rhetoric.

14.Anderson (1992:36-37) refers to Letwaba as 'one of the most outstanding black leaders in the history of the Apostolic Faith Mission'. Chandomba (2007:21) argues that his school was never recognised by the AFM of SA, 'probably because it was started by a Black African'. However, the minutes of the White Executive Council shows that this theological institution received recognition from the AFM of SA. The AFM of SA's structure in its first 90 years of existence allowed for a Workers' The AFM of SA's structure in its first 90 years of existence allowed for a
Council consisting of all ordained and retired pastors as well as representatives of all assemblies, an Executive Council consisting of the chairpersons of districts (regions), and District or Regional Council electing its own office bearers and (regions), and District or Regional Council electing its own office bearers and
operating in a defined geographic area. Until 1996 these structures were constituted along racial lines. 
not support her work and that the morale in the church was low (AFM of SA 1932b:1297, Minutes of the White Workers' Council; Langerman 1983:96). The Bible school closed, partly due to the economic hardship associated with the depression of the 1930s that lead to widespread poverty amongst South Africans. Many people had to leave their farms to work on the mines and in the cities (AFM of SA 1932a:1285, Minutes of the White Executive Council). ${ }^{15}$ It was decided that the AFM of SA would send travelling lecturers to assemblies to provide in the need for training (Wessels 2009:377).

From 1932 to 1935 only Letwaba's Patmos Bible school was in operation, while the church debated the need and necessity for a white Bible school in different meetings of the church. It recommended training, but stated that it should not be compulsory for prospective pastors (Wessels 2009:377). In June 1940 the AFM of SA appointed Charles Bennett as principal of a Bible school situated in Johannesburg with evening classes. ${ }^{16}$ This school started with four students (AFM of SA 1940:2220, Minutes of the White Executive Council). The school was closed at the end of 1947. Bennett, however, later served a second term (from 1955 to 1968) as principal of the white Bible school.

During the period between the 1940s and 1960s, a crucial shift in perspective gradually occurred within the AFM of SA (and the Pentecostal Movement at large) from, on the one hand, the notion that the anointing of the Spirit was all that was needed for an effective ministry, to, on the other hand, an understanding that a solid theological training is necessary for the challenges inherent to the ministry. However, there was always tension between the view that propagated only the work of the Spirit and the view that allowed for academic training (AFM of SA 1979b:46), and it remained the case until the 1990s. ${ }^{17}$ Leaders and members of the AFM of SA often expressed the fear that theological knowledge might become a substitute for the immediate working of the Spirit when the church makes theological training compulsory to enter the ministry. The general view was that revelational knowledge could be attained without using theological knowledge or scientific biblical exegesis as a measuring standard for the validity of any further revelation. ${ }^{18}$ For that reason the church

15.By 1929 the AFM of SA was near bankruptcy after the head office of the church was enlarged in the period leading up to the depression. Many members resigned out of fear that their property might be confiscated as the AFM of SA was a public body (Burger 1987:264-267).

16.The Bible school was not even named (Putter \& Lotter 2009).

17.Cf. Cronjé's argument (AFM of SA 1979b:46) that, even though the studies at AFM of SA Theological College was based on the matrix of the Baccalaureus Divinitatis degree with a strong emphasis on exegesis, the Pentecostal preacher would not need all these exegetical skills. The Holy Spirit reveals truth and the application of scientific knowledge is only introductory. ('Die Heilige Gees is tog die grootste scientific knowledge is only introductory. ('Die Heilige Gees is tog die grootste
openbaarder van waarheid, waarvan die toepassing van wetenskaplike kennis in openbaarder van waarheid, waarvan die toepassing van wetenskaplike kennis in dié verband maar slegs inleidend van aard is' ['The Holy Spirit is the greatest revelation of truth, and scientific knowledge is only introductory to this revelation'; author's own translation]). Putter (2009:197) correctly argues that Cronjé is a victim of dichotomist thinking when he perpetuates the tension between the work of the Spirit and scientific academic skills. This resulted in exegetical, Greek and Hebrew studies as well as in hermeneutics being devalued, because the idea existed that revelational knowledge could be obtained without exegetical labour that Dogmatics and Practical Theology were emphasised as the explanation and application of revelational knowledge (Erasmus 1996:112).

18. Even today this view has not disappeared. Some Pentecostal churches still do not require theological training. The effect of this view is that the study of the source languages, exegesis and hermeneutics was neglected in favour of Systematic Theology and Practical Theology. chose purposefully for Bible school training that was 'spiritual', Bible-centred and Bible-oriented, with the Bible serving as the main (and in many instances, the only) textbook (AFM of SA 1947:3094, Minutes of the White Executive Council).

Bennett, an Englishman, presented his lectures in English during a period of pro-German sentiments amongst some Afrikaans speaking people. This led to resistance from the side of some Afrikaans speaking members against the school and the introduction of an independent correspondence course in Afrikaans, a 'refresher course', prepared by Gerrie Wessels and F.P. Möller in 1946. Eventually this resulted in the closure of the English Bible school in 1947 due to a lack of interest (AFM of SA 1947:3018, Minutes of the White Executive Council). ${ }^{19}$ The White Executive Council approved the correspondence course in 1949 (AFM of SA 1949:3283, Minutes of the White Executive Council).

The AFM of SA opened a second Bible school for 'non-white' students in January 1951 at Rietfontein near Benoni with E. Cooksey as principal. In 1955 J.R. Gschwend established Leratong Bible School near Pretoria. Leratong had to close down in 1964 when the suburb was re-zoned as a 'white' area. The school was eventually reopened in Potgietersrus in 1968 and renamed as the Bantu Bible College. In 1971 the one-year study course was changed to a three-year programme (De Wet 1989:170). In 1975 the college moved to Soshanguve near Pretoria.

Training for mixed race started in the Cape under J. Gillingham, and for Indians in Natal under C.J.J. Nielsen - both in 1957 (Burger 1987:441).

Afrikaans speaking White people received training by means of a correspondence course for part-time students from 1946 to 1950. The church developed refresher courses for pastors as from 1952. It created an intramural department in 1954 with 325 correspondence students registered (AFM of SA 1950b:3524; 1954:4272, Minutes of the White Workers' Council). Although the church did not require a matriculation certificate as a prerequisite to register for the certificate presented by the Apostolic Bible College, a candidate could not be ordained without holding a matriculation certificate (AFM of SA 1958:4995, Minutes of the White Executive Council). Studies consisted of two years' theoretical training and one year of practical work under mentorship of a senior pastor (AFM of SA 1958:5137, Minutes of the White Executive Council). Some important progress was made.

\section{Era of theological colleges}

From 1970 onwards new developments led to a change from 'Bible school' training to theological training being accepted within the AFM of SA, a tendency followed by the rest of the Pentecostal Movement as the result of a new theological

19.Partly due to the fact its membership came mainly from non-professional and poorer groups, the political climate in the AFM of SA mostly represented conservatism (Wessels 2009:375, 378-379). 
paradigm that developed..$^{20}$ The AFM of SA accepted that its leaders and pastors should be trained sufficiently to lead believers in a responsible manner. Theological training in the AFM of SA became part and parcel of the development of the professional pastorate and the pastoral theological approach to the church (Burger \& Nel 2008:393). ${ }^{21}$ As theological training became compulsory for the ordained ministry, the gap between the 'clergy' and 'laity' broadened (Goff 2008:91).

In 1964 the White Executive Council started negotiations with the University of South Africa (Unisa) to present a diploma and degree acknowledged by this university (AFM of SA 1964a:6479, Minutes of the White Executive Council). Eventually negotiations followed with other universities like the Potchefstroom University for Christian Higher Education (PU for CHE), Rand Afrikaans University (RAU), the University of the Witwatersrand, the University of Zululand and the University of London (AFM of SA 1972:1; 1979a:2, Minutes of the Theological College Committee; AFM of SA 1985:73; AGS Teologiese Kollege Jaarverslag 1993:1). At this stage (1973) only Unisa agreed to an intramural Bachelor of Arts degree in theology (AFM of SA 1973a:1, Minutes of the White Curatorium, 1974:82).22 The curatorium, however, recommended in 1975 that the Executive Council should terminate the agreement, because they were not satisfied with what they perceive to be the liberal content of the curricula of Unisa's Faculty of Theology (AFM of SA 1973a:1, Minutes of the White Curatorium, 1974:82).

Frank H.J. Cronjé succeeded Bennett as principal of the Apostolic Bible College in 1969, and the next year the church changed the name of this 'white' college to AFM of SA Theological College (AFM of SA 1969:7618, Minutes of the White Executive Council), reflecting the change from a 'Bible school' model to more thorough theological training. In 1974 it introduced a new language medium (Afrikaans) and a new approach to training that was organised along the lines of the acknowledged six theological disciplines, including Hebrew and Greek proficiency, reflecting the need that its pastors should receive a proper theological training. ${ }^{23}$ Furthermore, as from 1974 it made a matriculation certificate a prerequisite (AFM of SA 1973b:1, Minutes of the White Executive Council)

20.The new theological paradigm originated with the socio-economic and intellectual development of members of Pentecostal churches. In its earliest days the movement consisted mostly of the poor and needy, the 'lower strata', with notable exceptions (cf. Niebuhr 1929:40-42). By the middle of the 20th century the composition of Pentecostal churches' members shows a variety of rich and poor, composition of Pentecostal churches members shows a variety of rich and poor,
learned and unlearned (Synan 1997:203-205), although it did not reflect the composition of the surrounding society. Members insisted that preaching should be biblically based and theologically sound and that the church should order its worship services to accommodate seekers that would be deterred by an unorderly
liturgy. Leaders in the Pentecostal Movement also reflected these developments liturgy. Leaders in the Pentecostal Movement also reflected these developm
and they argued for theological training contra mere Bible school training.

21.Turnage (2003:21) defines it as the development of an integrated, Pentecostal liberal education to realise Jesus' call to study and action.

22.AFM of SA members shared a perception that the existing agreements the universities had with traditional churches to train candidates for the ministry, prevented the universities from allowing AFM of SA students. In the end, however, technical issues like the content of curricula and the AFM of SA's request to participate in the training process caused the cessation of negotiations (AFM of SA 1975:394, Minutes of the White Curatorium).

23.As a part of the policy of the AFM of SA Theological College it was required that lecturers had to have earned at least a Baccalaureus Divinitatis or equivalent Master's degree in Theology, articulating into the curricula of the College based on the customary division of theological subjects of this postgraduate qualification the customary division of theological subjects of this postgrad
(AFM of SA 1979b:46; Burger \& Nel 2008:394; Putter 2009:197). for registering for a diploma consisting of three years' theoretical training, followed by a probationary year (AFM of SA 1969:7476, Minutes of the White Executive Council).

The AFM of SA Theological College started negotiations with RAU again in 1975 (AFM of SA 1975:1, Minutes of the White Curatorium), but the parties only reached an agreement in 1993, allowing the AFM of SA Theological College to develop and award a Bachelor of Theology and a Bachelor of Theology (Honours) degree with a four-year study programme (AGS Teologiese Kollege Jaarverslag 1993:1), and opening the door to postgraduate studies (Burger \& Nel 2008:400). The church allowed students without university admission to do a four-year diploma, and students older than 25 years could complete a three-year diploma to qualify to be ordained (AFM of SA 1969:7618, Minutes of the White Executive Council; Burger 1987:441). In 1989 W.J. Hattingh became the rector of the AFM of SA Theological College and in 1997 the church changed the College's name to Auckland Park Theological Seminary (ATS). The agreement signed in 1993 between the AFM of SA Theological College and RAU, resulting in ATS becoming a theological school of this university, constituted a breakthrough for theological training in the Pentecostal domain (Putter 2015:1).

At the same time the racially divided theological education came under pressure despite of the fact that this division was the result of government policies (i.e. the Group Areas Act). The Central Bantu Bible College of the AFM of SA experienced student boycotts in 1991 and the college had to be closed down for a period. The Black Executive Council responded by deciding to appoint a black pastor to become the principal (AFM of SA 1991:243; Minutes of the Black Executive Council). In 1994 George Mahlobo was appointed as rector (Burger \& Nel 2008:397).

In 1992 the three former 'non-white' sections of the AFM of SA united to form the Composite Division, with only one theological institute on the premises of the Central Bible College and with campuses in Durban and Kuilsriver as satellites (AFM of SA 1987:853, Minutes of the White Executive Council). ${ }^{24}$

\section{Unification of theological colleges}

With the dawn of a new political dispensation 1994, the AFM of SA followed suit and changed its strategy to reflect the new political vision of national unity. On 03 April 1996 the process of structural unification in the AFM of SA was completed. Its next task was to unite the theological institutions to concur with the amalgamation of the different regions and departments. When the AFM of SA adopted a new constitution in 2000, the process had been completed except

\footnotetext{
24.The level of training differed between these 'non-white' colleges, as demonstrated by the admission requirements. In 1970 black students were allowed with a standard 6 certificate (AFM of SA 1970:2, Minutes of the Central Missionary Committee) and mixed race students with a standard 8 certificate (AFM of SA 1973:1). The General Missionary Council, responsible for the three 'non-white' colleges, tried in 1983 to standardise the training, but without any success (AFM of SA 1983:4, Minutes of the General Missionary Council). These differences in standards made it difficult for the different colleges to amalgamate after 1996 (Putter 2006:1).
} 
for the two theological institutions: the AFM of SA Theological Institute at Soshanguwe and the AFM of SA Theological College at Auckland Park (Burger \& Nel 2008:402).

As explained, shortly before the unification of the AFM of SA, the Composite Division of it amalgamated the three racially based theological institutions in 1995: the Central Bible College, Sarepta Theological College and Covenant Bible College. However, the resultant AFM of SA Theological Institute did not function well and in reality each institution kept on functioning independently (Burger \& Nel 2008:401). Eventually, the Composite Division agreed that Sarepta and Covenant would continue as self-sustaining institutions (AFM of SA 1996:4, Minutes of the Curatorium). In 1996 the Covenant Bible College requested to be integrated into the ATS, presumably to enjoy the benefits of ATS's cooperation with RAU and to survive financially (ATS 2008b:3). The church granted the request (Clark 1999:5). At this stage the AFM of SA had two official colleges, ATS and AFM of SA Theological Institute as well as one unofficial college, namely Sarepta Theological College. The subsidy provided by the AFM of SA for theological training was initially divided equally between the institutions. The Curatoria of ATS and AFM of SA Theological Institute reached an agreement on 11 November 1996 to unify (AFM of SA 1996:2, Minutes of the Curatorium). The AFM of SA Theological Institute requested that the agreement be terminated on 1 September 1997, leading to a new process of unification (AFM of SA 1997:4, Minutes of the Curatorium).

In 1998 the National Leadership Forum of the AFM of SA decided to recognise ATS, AFM of SA Theological Institute and Sarepta Theological College as distinct institutions with own statutes and rules approved by the National Leadership Forum. With its decision the church recognised that each institution appeals to and caters for a specific niche market. In 2000 the church recognised the status quo in policy when the new Constitution of the AFM of SA made provision for this diversity (AFM of SA 2000:9.3). It gave the AFM of SA Theological Institute, ATS and Sarepta Theological College legal standing independent of each other. The institutions were open to all races, although the culture of each was (at least initially) racially defined, and academic standards also differed between them (Burger \& Nel 2008:403). The church temporarily suspended talks about consensus on the unification of the colleges.

The new Constitution of the AFM of SA (2000) required each college to provide the National Leadership Forum ${ }^{25}$ with its statutes and regulations. The church approved the statutes of ATS in 2003, although the other institutions did not respond.

The Republic of South Africa (1997:50) required each of the institutions to be registered as entities that provide higher education to the AFM of SA, requiring that a non-profit company be registered for each institution. The AFM of SA Theological College complied with this new government law

25. In the earlier constitution the National Leadership Forum was designated as Executive Council. by establishing an Article 21 Company in 2001. At the same time it changed its operational name to ATS (ATS 2002:1). In 2004 the ATS was provisionally registered as a private higher education institute.

All attempts to unify the institutions failed. ${ }^{26}$ Informal talks between the institutions continued and some of the participants experienced the diversity within the AFM of SA to be of such an extent that common ground could not be found (Burger \& Nel 2008:402-403). ${ }^{27}$ In March 2006 the National Leadership Forum appointed a standing committee to define a policy regarding ministerial training (Letter to committee members, standing committee for ministerial training of the National Leadership Forum in 2006 by P. de Witt). Members of the committee differed as to the intent of the instruction of the National Leadership Forum with ATS interpreting it as unification of existing structures and other members as the creation of a new structure (Hattingh 2006:3). ${ }^{28}$ As a result the National Leadership Forum established a new Directorate for Education and Training in November 2006 and approved a new curriculum framework to be implemented in January 2009. The forum presumed that since the three institutions were not prepared to unite or merge, they had to be absorbed and incorporated into this new institution. The church persuaded the institutions to sign a Memorandum of Agreement for their incorporation into the new seminary. The AFM of SA changed its constitution in 2008 to remove the constitutional existence of ATS, Sarepta Theological College and AFM of SA Theological Institute in favour of the Pentecostal Theological Seminary (Putter 2010a:6). At last it seemed that theological training was also unified.

\section{Feud between Auckland Park Theological Seminary and the Apostolic Faith Mission of South Africa}

After the three institutions had signed the Memorandum of Agreement, ATS withdrew from the unity process on 19 May 2008 and decided to continue independently from the Pentecostal Theological Seminary as indicated in a letter sent on 10 October 2008 by Prof Jan Hattingh to all ATS students (ATS 2008b:1). The reason ATS gave for their withdrawal was the lack of transparent negotiations and the alleged forced incorporation of the existing colleges into the Pentecostal

26.The AFM of SA'S vice-president, Frank Chikane, was tasked to facilitate the unification. He called a meeting of four representatives from each of the two theological institutions and, in addition, allowed AFM of SA Theological Institute to bring along representatives from the campus in Cape Town (the former Sarepta Theological College) and the campus in Durban (Covenant Bible College) as equal representatives. In this way ATS felt marginalised, since 12 representatives stood against four. In this way the efforts to unite the two institutions failed (in a letter from W.J. Hattingh 2006:1-3 to V. Atterbury on 28 September; Burger \& Ne 2008:403)

27.Factors that complicated cooperation and the process of unification are, amongst others, different training models, different standards and different cultural backgrounds as well as a deep seated historical suspicion between races (Putter 2010b:3).

28.In a letter from W.J. Hattingh to V. Atterbury on 28 September 2006, Hattingh argues that ATS's interpretation was perceived as a racist attempt of the stronger party to obstruct unification. 
Theological Seminary. At the same time they declared their willingness to participate in a unification and arbitration process according to their interpretation of the National Leadership Forum instruction of 2005 (ATS 2008b:3-5). The National Leadership Forum responded by instituting an ecclesiastical court case against ATS, which the National Leadership Forum eventually lost.

The Pentecostal Theological Seminary signed an agreement with Global University of the Assemblies of God in the United States to present the degree programme of Global University to the AFM of SA students. The programme is based on a Bible college model with subjects built on Bible study rather than academic theology as a scrutiny of the curricula shows. All students are enrolled as distance learning students with classes held at local churches with the help of local facilitators.

The AFM of SA changed the members of the Article 21 Company, previously owned by ATS, because the ATS signed the Memorandum of Agreement as mentioned above according to which ATS was incorporated into the new AFM of SA Pentecostal Theological Seminary. (It was a document that described the unification process and not a document in which the ATS confirmed its incorporation with the new institution, or that it has stopped to exist. ATS withdrew from this process, because the modus operandi of the document was, according to them, not followed.) When the ATS withdrew from the process of unification through incorporation, it requested the AFM of SA to revert to the original members of the Article 21 Company. When the AFM of SA refused to comply with the request, ATS started a legal process to regain the company (cf. SAFFLII 2013). AFM of SA 2014:157-209 (Minutes of the General Business Meeting) contains more information and the judgement.

At first the Witwatersrand High Court granted ATS an interim order that prevented the AFM of SA from using the company, but in 2011 it set the interim order aside with costs to ATS. ATS applied for leave to appeal, but it was denied (G. Mahlobo in Circular GS.02.2011 to all pastors and others by the General Secretary of the AFM of SA dated 28 October, 2011).

ATS then applied for leave to appeal to the full bench and in December 2013 their case was dismissed - again with costs. The court pronounced that the Article 21 Company belongs to the AFM of SA. However, a new legal battle ensued when ATS refused at the beginning of 2014 to vacate their premises in Auckland Park, Johannesburg.

In the meantime, the University of Johannesburg (since 01 January 2005 the new name of RAU) terminated its 17-year contract with ATS in 2008. Its motivation was that it is a secular university and could not accommodate ATS as a Christian theological institution. ATS immediately started negotiations with North-West University, which led to the signing of an agreement in 2010. According to the agreement qualifying ATS alumni can register for a Masters or Doctoral qualification programme of the North-West University (AFM of SA 2012b:108-109; ATS 2008a; Putter 2009:197).

\section{New Era: The Apostolic Faith Mission of South Africa and the North-West University}

In March 2011, when Prof. Marius Nel accepted a call to the AFM of SA assembly in Polokwane, the Faculty of Theology of the North-West University's Dean, Prof. Fika J. van Rensburg (2010-2014), in cooperation with Nel, established an open learning centre in the Limpopo Province. The NorthWest University presents degree programmes in Theology as well as in Education and Health Sciences at this facility in support of the vision of Dr Theuns Eloff (the Vice-Chancellor of the North-West University, 2002-2014) to take tertiary education to the poor in rural areas. The AFM Taberna Dei assembly in Polokwane, under leadership of Danie Oosthuizen, and North-West University reached an agreement and the first students registered in 2012. ${ }^{29}$

On 21 June 2011 the office bearers of the AFM of SA ${ }^{30}$ had a meeting in the Limpopo Province and invited Pastor Oosthuizen and Prof. Nel to report on the agreement between Taberna Dei Academy and the North-West University. The AFM of SA's president, Dr Isak Burger, became convinced that the AFM of SA should enter into negotiations with the North-West University to discuss possible future cooperation between the AFM of SA and the North-West University. Representatives of the AFM of SA and the North-West University held preliminary meetings on 08 November 2011 and again on 25 April 2012. The AFM of SA appointed a task team in the persons of Drr. Vincent Atterbury and Japie la Poorta. This task team met on 18 May 2012 and again on 06 July with a task team of the Faculty of Theology of the North-West University, viz. Prof. Fika J. van Rensburg, Dr Raymond Potgieter and Mr. Mathys Bornman.

The National Leadership Forum of the AFM of SA decided in July 2012 to approve in principle that the it may enter into a comprehensive agreement with the North-West University, which includes the development of a Bachelors of Theology and Bachelor of Arts (Honours) curriculum for students who wish to enter the ordained ministry in the AFM of SA (Faculty of Theology 2015:37). This led to the signing of a Memorandum of Agreement on 25 September 2012 according to which (i.a.) the:

AFMTC may indicate to the Faculty of Theology of the NorthWest University the need for paradigm-specific content for specific modules to serve the specific needs of the AFM Church. The Faculty will approve these modules according to the policies and procedures of North-West University. (AFM of SA 2012a, Addendum 4.2)

29.Information in this section was taken from the unpublished minutes of the various meetings.

30.The AFM of SA' office bearers are elected at the Business Meeting of representatives of all assemblies every four years. The office bearers who were elected in 2011 were Drs Isak Burger and Japie LaPoorta, Pastors George Mahlobo and Trevor Herbert. 
A number of whole modules in this programme are written from a pentecostal perspective, others contain sections which differentiate between a reformed and a pentecostal perspective, and in some there is no differentiation. As with all North-West University qualification programmes, this B.Th. qualification programme meets the requirements of North-West University's SAQA registered outcomes. This B.Th. qualification programme is available as contact programme on the Potchefstroom Campus and as ODL Programme at the Open Learning Centres of the North-West University, as agreed with the AFM. (Faculty of Theology 2015:14)

The paradigm specific (sections of) modules include subjects like dogmatics, liturgy, church history, hermeneutics and missiology.

The AFM of SA cancelled its contract with Global University at the end of 2013 and its first students registered with the North-West University in 2013. ${ }^{31}$

\section{Scholarly coming of age}

The earnest attempt of the AFM of SA to provide in-depth theological training is evidenced by at least two phenomena: Firstly, the fact that many of the AFM of SA leadership and pastors serving as lecturers for the training of pastors hold a relevant doctorate from one of the mainline South African universities; and secondly, most of these theologians are not only well-published in South African and international scholarly journals, but they are also active participants in the Research Unit of the Faculty of Theology of the North-West University and other universities. This participation includes serving as study leaders for masters students and as promoters for doctoral students.

\section{Synthesis}

Theological training in the AFM of SA has followed the same long and arduous journey over the past century that the Pentecostal Movement has generally followed. It started with the viewpoint that no training was necessary, because the Spirit would empower and reveal the gospel truths to believing witnesses. Gradually the movement recognised the need for better training in the form of the Bible school model. Eventually it realised the necessity proper theological training and university training was sought.

That this (presently) final stage in the development has been reached, is evidenced by the Memorandum of Agreement with the North-West University as well as the fact that both the AFM of SA's leadership and the members involved in the training of pastors not only profess the importance of proper theological training, but hold a relevant doctorate

31.The Fuil Gospel Church of God in Southern Africa followed suit and entered into a similar agreement with North-West University to present the Bachelors of Theology curriculum that is in the process of being registered as 'B.Th. in Pentecostal Theology'. Their first students registered in 2014. During the course of 2014 the Members in Christ Association (MICA) decided to move the theologica training of their students to North-West University and an agreement was signed in the same year, with the first students to register with the North-West University in 2015 . from one of the mainline South African or international universities.

There are many reasons for the AFM of SA's change of heart on theological training. One of these is the composition of the AFM of SA's membership and the fact that the way other denominations treated the AFM of SA, exerted influence on the stance it took on theological training.

Another reason is the fact that an institution was found that has no dichotomy between good and solid theological training on the one hand, and being equipped by the Holy Spirit on the other. The Faculty of Theology of the NorthWest University professes its 'recognition that the Word of God, the Bible, originated through the inspiration of the Holy Spirit and that it is authoritative' and that in their practice of theology as a science, they:

recognise and respect the Reformational view of God and the written Word of God as the particular revelation of God. The Bible - the particular revelation of God, in addition to his revelation in creation - constitutes the object of scientific study. Teaching-learning, research and the application of expertise are conducted on this revelation and in the light thereof, through the illuminating work of the Holy Spirit. (Faculty of Theology of the North-West University 2015)

The AFM of SA respects this reformational foundation and inclusive approach. Its experience is that its staff members and students are being accommodated while sharing in the foundation and ethos of the Faculty of Theology, which 'entail a constant analytical, critical and Reformational scientific study of all paradigms (including our own), as well as the study of other theological paradigms and traditions' (Faculty of Theology of the North-West University 2015).

\section{Conclusion}

The AFM of SA has found a home and vehicle for its theological training in an institution that approaches the lectern and the pulpit in the very same way: with rationality and spirituality integrated and intertwined, acknowledging the authority of the Bible as the particular revelation of God and conducting teaching-learning and research on this revelation, and in light thereof, through the illuminating work of the Holy Spirit.

\section{Acknowledgements Competing interests}

The authors declare that they have no financial or personal relationship(s) that may have inappropriately influenced them in writing this article.

\section{Authors' contributions}

M.N. wrote the first part, about theological training in the AFM of SA, and F.j.v.R. the second part, about theological training provided by North-West University for the AFM of SA. 


\section{References}

AGS Teologiese Kollege Jaarverslag, 1993, in W.J. Hattingh (ed.), AGS Blanke Uitvoerende Raadverslag, bl. 1-12, AGS, Johannesburg.

Anderson, A., 1992, Bazalwane: African Pentecostals in South Africa, UNISA, Pretoria.

Anderson, R.M., 1979, Vision of the disinherited: The making of American Pentecostalism, Hendrickson, Peabody, MA.

Anon., 1908, 'Witness', Apostolic Faith, 2 May, p. 2.

AFM of SA see Apostolic Faith Mission of South Africa.

Apostolic Faith Mission of South Africa, 1909, 'Minutes of the White Executive Council', archived.

Apostolic Faith Mission of South Africa, 1917, 'Minutes of the Black Executive Council', archived.

Apostolic Faith Mission of South Africa, 1920a, 'Minutes of the White Executive Council', archived.

Apostolic Faith Mission of South Africa, 1920b, 'Minutes of the Workers' Council', archived.

Apostolic Faith Mission of South Africa, 1921, 'Minutes of the White Executive Council', archived.

Apostolic Faith Mission of South Africa, 1923, 'Minutes of the White Executive Council', archived.

Apostolic Faith Mission of South Africa, 1926, 'Minutes of the White Executive Council', archived.

Apostolic Faith Mission of South Africa, 1932a, 'Minutes of the White Executive Council', archived.

Apostolic Faith Mission of South Africa, 1932b, 'Minutes of the White Workers' Council', archived.

Apostolic Faith Mission of South Africa, 1936, 'Minutes of the White Workers' Council', archived.

Apostolic Faith Mission of South Africa, 1939, 'Minutes of the White Workers' Council', archived.

Apostolic Faith Mission of South Africa, 1940, 'Minutes of the White Executive Council', archived.

Apostolic Faith Mission of South Africa, 1944, 'Minutes of the White Executive Council', archived.

Apostolic Faith Mission of South Africa, 1947, 'Minutes of the White Executive Council', archived.

Apostolic Faith Mission of South Africa, 1949, 'Minutes of the White Executive Council', archived.

Apostolic Faith Mission of South Africa, 1950a, 'Minutes of the White Executive Council', archived.

Apostolic Faith Mission of South Africa, 1950b, 'Minutes of the White Workers' Council', archived.

Apostolic Faith Mission of South Africa, 1954, 'Minutes of the White Workers' Council', archived.

Apostolic Faith Mission of South Africa, 1958, 'Minutes of the White Executive Council', archived.

Apostolic Faith Mission of South Africa, 1961, Constitution, Johannesburg.

Apostolic Faith Mission of South Africa, 1964a, 'Minutes of the White Executive Council', archived.

Apostolic Faith Mission of South Africa, 1964b, Yearbook, AFM Printers, Johannesburg.

Apostolic Faith Mission of South Africa, 1969, 'Minutes of the White Executive Council', archived.

Apostolic Faith Mission of South Africa, 1970, 'Minutes of the Central Missionary Committee', archived.

Apostolic Faith Mission of South Africa, 1972, 'Minutes of the Theological College Committee', archived.

Apostolic Faith Mission of South Africa, 1973a, 'Minutes of the White Curatorium', archived.

Apostolic Faith Mission of South Africa, 1973b, 'Minutes of the White Executive Council', archived.

Apostolic Faith Mission of South Africa, 1974, 'Verslag van prinsipaal', in F.H.J. Cronje (ed.), AGS Werkersraadverslagbundel, AGS, Johannesburg.

Apostolic Faith Mission of South Africa, 1975, 'Minutes of the White Curatorium', archived.

Apostolic Faith Mission of South Africa, 1976, 'Minutes of the White Executive Council', archived.

Apostolic Faith Mission of South Africa, 1979a, 'Minutes of the Theological College Committee', archived.

Apostolic Faith Mission of South Africa, 1979b, 'Verslag van prinsipaal', in F.H.J. Cronjé (ed.), AGS Werkersraadverslagbundel, AGS, Johannesburg.

Apostolic Faith Mission of South Africa, 1983, 'Minutes of the General Missionary Council', archived.

Apostolic Faith Mission of South Africa, 1985, 'Verslag van prinsipaal', in F.H.J. Cronjé (ed.), AGS Werkersraadverslagbundel, AGS, Johannesburg.
Apostolic Faith Mission of South Africa, 1987, Minutes of the White Executive Council, archived.

Apostolic Faith Mission of South Africa, 1991, 'Minutes of the Black Executive Council', archived.

Apostolic Faith Mission of South Africa, 1996, 'Minutes of the Curatorium', archived. Apostolic Faith Mission of South Africa, 1997, 'Minutes of the Curatorium', archived.

Apostolic Faith Mission of South Africa, 2000, Constitution of the Apostolic Faith Mission of South Africa, A church incorporated in terms of the Apostolic Faith Mission of South Africa (Private Act, 24 of 1961, as amended), Johannesburg.

Apostolic Faith Mission of South Africa, 2012a, Memorandum of Agreement between die AFM and the North-West University \& Addendum, Johannesburg.

Apostolic Faith Mission of South Africa, 2012b, Education and Training Department of the AFM of SA by the Director, Dr. V. Atterbury: 'Report to September 2012 General Business Meeting', in General Business Meeting Agenda, pp. 1101-1115. AVA, Johannesburg.

Apostolic Faith Mission of South Africa, 2014, 'Minutes of the General Business Meeting', archived.

Armstrong, K., 2014, Fields of blood: Religion and the history of violence, Bodley Head, London.

ATS see Auckland Park Theological Seminary

Auckland Park Theological Seminary, 2002, Institutional statutes, Johannesburg.

Auckland Park Theological Seminary, 2008a, History, viewed 09 September 2015, from http://www.ATS.ac.za/history

Auckland Park Theological Seminary, 2008b, Prospectus, Johannesburg.

Barr, J., 1983, Holy Scripture: Canon authority criticism, Clarendon, Oxford.

Burger, I. \& Nel, M., 2008, The fire falls in Africa: A history of the Apostolic Faith Mission of South Africa. Christelike Uitgewersmaatskappy, Vereeniging.

Burger, I.S., 1987, 'Geloofsgeskiedenis van die Apostoliese Geloofsending van SuidAfrika 1908-1958', D.D. proefskrif, University of Pretoria, Evangelie Uitgewers, Johannesburg.

Carlisle, W., 1932, 'Training', Herlewings Nuus 3(26), 21.

Chan, S., 2000, Pentecostal theology and the Christian spiritual tradition, Sheffield Academic Press, Sheffield. (JPTSup 21).

Chandomba, L., 2007, The history of the Apostolic Faith Mission and other Pentecostal missions in South Africa, AuthorHouse, Keynes.

Clark, M.S., 1999, Verslag voorgelê aan die Bestuursraad van die AGS Teologiese Kollege (AGSTK) op 28 Oktober, AGS, Johannesburg.

Craven, G., 2009, 'George Fox - Early Quaker leader, man of the Spirit', Journal of the European Pentecostal Theological Association 29(1), 57-71.

De Beer, F.J., 2013, 'The valence of Spirit manifestation, and its influence on the transformation of the mind and redemption of the body and flesh according to Romans 8 and 12 and its application in a secular society', D. Litt et Phil. dissertation, Faculty of Theology, University of Johannesburg.

De Wet, C.R., 1989, 'The Apostolic Faith Mission in Africa: 1908-1980: A case study in church growth in a segregated society', unpublished PhD thesis, Faculty of Theology, University of Cape Town.

Du Plessis, L., 1984, Pinkster panorama: 'n Geskiedenis van die Volle Evangelie-Kerk van God in Suidelike Afrika, D.D. proefskrif, Fakulteit Teologie, University of Pretoria, VEK, Irene.

Erasmus, L.J., 1996, 'Theological education in the Apostolic Faith Mission of South Africa', unpublished DTh dissertation, Faculty Theology, University of South Africa.

Eybers, I.B., König, A. \& Stoop, J.A., 1978, Introduction to theology, NG Kerkboekhandel, Pretoria.

Faculty of Theology, 2015, Calendar 2015, North-West University, Potchefstroom

Faculty of Theology of the North-West University, 2015, Reformational foundation, viewed 14 January 2015, from http://www.North-West University.ac.za/theologyreformed-foundation

Friesen, A., 2009, 'The called out of the called out: Charles Parham's doctrine of Spirit baptism', Journal of the European Pentecostal Theological Association 29(1), 43-56.

Garrard, D., 2009, 'Leadership versus the congregation in the Pentecostal/Charismatic Movement.' Journal of the European Pentecostal and Theological Association 29(2), 90-103

Goff, C.W., 2008, Measuring the clergy/laity gap and its effect on church health and outreach, ProQuest, Eisenhower.

Hattingh, W.J., 2006, Letter from W.J. Hattingh addressed to V. Atterbury, Director of the Pentecostal Theological Seminary, on 28 September 2006, AFM Archive, Johannesburg.

Hayford, J.W., 2006, The charismatic century: The enduring impact of the Azusa Street Revival, Warner Faith, New York.

Langerman, J.L., 1983, 'Apostolic Faith Mission of South Africa: A revitalization of the theological concepts of church ministry', unpublished D.Min. dissertation, Faculty Theology, Fuller Theological Seminary.

Letson, H., 2007. 'Pentecostalism as a paradigm shift: A response to Hans Kung's paradigmatic model', Journal of the European Pentecostal Theological Association 27(2), 104-117.

Ma, W., 2005, 'Full circle mission: A possibility of Pentecostal missiology', Asian Journal of Pentecostal Studies 8(1), 5-27.

Maré, L.P., 2005, 'AGS-pastore se belewenis van hulle teologiese opleiding', Verbum et Ecclesia 26(2), 432-446. 
Möller, F.P., 1975, Die diskussie van die charismata soos wat dit in die Pinksterbeweging beoefen word. Evangelie Uitgewers, Braamfontein.

Nel, M., 1993, 'n Man deur God in 'n hoek gedryf, John G Lake Stigting, Johannesburg. Niebuhr, H.R., 1929, The social sources of denominationalism, Shoestring, Hamden, CT.

Pillay, G.J., 1994, 'Christianity in the years before union', in J.W. Hofmeyr \& G.J. Pillay (eds.), A history of Christianity in South Africa, vol. 1., pp. 172-199, HAUM Tertiary, Pretoria.

Putter, A., 2009, 'Aucklandpark Teologiese Seminarium: Die hartseer verlede en uitdagings in die nuwe millennium', Studia Historiae Ecclesiasticae, suppl. ser. 35 $193-210$

Putter, A.P.J., 2006, 'Die voortgesette akademiese ontwikkeling van die AGS-pastor', D.Litt. et Phil. Proefskrif, Universiteit van Johannesburg.

Putter, A.P.J., 2010a, 'Teologiese opleiding in die AGS-kerk: Verkennende en ontwikkelende beskouings vir die nuwe millennium', HTS Teologiese Studies/ Theological Studies 66(1), 768, 9 p. http://dx.doi.org/10.4102/hts.v66i1.768

Putter, A.P.J., 2010b, 'Riglyne vir voortgesette teologiese opleiding: Uitdagings vir die AGS-kerk', Verbum et Ecclesia 31(1), 417, 8 p. http://dx.doi.org/10.4102/ve. v31i1.417

Putter, A.P.J, 2015, History of the ATS, viewed 01 September 2015, from http://www. ATS.ac.za/history

Putter, A. \& Lotter, G., 2009, 'Die ontwikkelingsproses van teologiese opleiding in die Apostoliese Geloofsending', Studia Historiae Ecclesiasticae 35(1), 6-7.

Rance, D., 2008, 'Fulfilling the apostolic mandate in apostolic power: Seeking a Spiritdriven missiology and praxis', paper presented at inaugural address as J. Philip Hogan Professor of World Missions at Assemblies of God Theological Seminary, Springfield, Missouri, TX, 20th January 2008.
Reidt, W., 1989, John G. Lake: A man without compromise, Harrison House, Tulsa, OK. Republic of South Africa, 1997, Higher education act 101, Amendment Act 55 of 1999, Government Printer, Pretoria.

Robeck, C.M., 2006, The Azusa Street mission and revival: The birth of the global Pentecostal movement, Thomas Nelson, Nashville, TN.

SAFFLII see Southern African Legal Information Institute.

Southern African Legal Information Institute, 2013, AFM Theological College and Others $v$ National Leaders Forum of the the Apostolic Faith Mission of South Africa, represented by the National Office Bearers and Others (A255/2012) ZAGPPHC 331, viewed 01 September 2015, from http://www.saflii.org/za/cases/ ZAGPPHC/2013/331.htm

Synan, V., 1997, The Holiness-Pentecostal tradition: Charismatic movements in the twentieth century, 2nd ed., William B. Eerdmans, Grand Rapids, MI.

Turnage, M., 2003, 'The early church and the axis of history and Pentecostalism Facing the 21st century: some reflections', Journal of the European Pentecostal Theological Association 23, 4-29.

Van der Spuy, M.A., 1985, 'Die spanning tussen vryheid en formalisering ten opsigte van die liturgiese verskuiwinge binne die Apostoliese Geloof Sending van SuidAfrika', ongepubliseerde M.Th. verhandeling, Fakulteit Teologie, UNISA.

Van Staden, A.J., 1980, Die Apostoliese Geloof Sending van Suid-Afrika: Hulle leer getoets aan die Skrif, HAUM, Pretoria.

Warrington, K., 2003, 'Would Jesus have sent his disciples to Bible College?', Journal of the European Pentecostal Theological Association 23, 30-44.

Wessels, W.J., 2009, 'Skrifgebruik en samelewing: Die Apostoliese Geloofsending van Suid-Afrika', In die Skriflig 26(3), 369-384. 